\title{
The Milieu Weighing Down Social Workers' Effectiveness and Efficiency in South Africa: A Literature Review
}

\author{
Prof. S. M. Kang'ethe \\ University of Fort Hare, Department of Social Work and Social Development, \\ Box X1314, Alice. 5700, South Africa \\ Email: skangethe@ufh.ac.za \\ Mr. Tatenda Manomano \\ PhD in Social Work Student, University of Fort Hare, Box X1314, Alice. 5700 \\ Email:200706055@ufh.ac.za
}

Doi:10.5901/mjss.2014.v5n27p1379

Abstract

Although ironically social work profession has achieved many things globally, it is unfortunate that in African countries, many challenges still befall it and therefore affecting the social workers' effectiveness in effectuating their duties and roles. This is a serious quagmire that call for urgent address and redress. This paper has adopted a review of literature methodology. The following environment has been found to weigh down social workers' effectiveness and efficiency: poor funding or lack of finances to enhance their performance; lack of infrastructure and resources to support social workers' tasks and roles; poor supervision affecting social workers growth and their professionalism, poor implementation of policies to secure social workers in their service delivery milieu, and challenges associated with competence levels among the social workers. The paper recommends for a strong synergy between the government and other stakeholders in order to improve the social work environment in South Africa.

Keywords: Developing countries, Developed countries, competence levels, infrastructure, Social Workers; versatility, occupational hazards, compensation

\section{Problem Statement}

The prevalent perfidious circumstances in which social workers operate continue to spell a blow to their effectiveness and thereby compromising their clients' the social, psychological, developmental and public health well-being (International Federation of Social Workers (IFSW), 2012). Such circumstances especially in the developing part of the world such as South Africa include crime, violence, war, poverty, lack of resources, corruption on local, national and state levels, lack of education, and low status of women (United Nations Department of Economic and Social Affairs (UN-DESA), 2013). These circumstances have derailed the social work profession from adequately defending and contending for the rights and the needs of the people they serve. Given the fact that South Africa has a huge population of vulnerable and needy people, and hence a huge need for the services of the social workers, exploring and examining the circumstances surrounding the social work operations and implementation is critical and pivotal. This is to ensure that the government and other related bodies adequately respond to these challenges and optimistically adopt a paradigm shift to enhance and bolster social work profession. This is with the aim of increasing people's social functioning.

\section{Methodology}

This paper uses a review of literature methodology. The paper has used United Nations publications, journals, books and other news articles where appropriate. The literature collected from these documents establishes the platform for debate and discourses with an aim to raise awareness on the challenges faced by social workers in South Africa in an endeavour to ensure that service delivery can be strengthened and augmented. 


\section{Introduction and Background}

Historically, social work profession developed or began due to the need to address the vulnerable people's philanthropic and charity needs during the $19^{\text {th }}$ Century and has since spread to other countries (Segal, Gerdes \& Steiner, 2007; Sheafor \& Horejsi, 2008). Social work is a profession that is widely known to be useful in enhancing the social functioning of the people in case work, group work, community work, and even through research enterprise (Segal et al, 2007. Historically, it is reported that the first social work class was offered at Columbia University in 1898 and since then social workers have been at almost all the corners of the globe engaging in philanthropy, charity and private work (National Association of the Social Workers (NASW), 2014).

Before making a succinct assessment of the social workers in different regions of the world, perhaps it is good to point out the diametrically opposed conditions in which the social workers of the developed part of the world and the developing ones operate. Perhaps this can help the readers to appreciate the prevalent output in these two different millieu. For example in most developed countries such as America, the work of social workers is duly recognized and the social workers compared to those of the developing part of the world may be experiencing some significant sense of professional dignity and satisfaction. Indubitably, a conducive working environment is in itself an incentive and a pointer to increased output (Kang'ethe, 2011; Lawler, 1994). It is therefore of central importance to consider in depth the environments in which social workers operate in different countries, if possible with the hope of working to change policies that could be responsible for the environment, help restructure them, or change the mindset of the workers.

While significant and appreciable satisfaction of the people served by social workers in especially African countries is something the countries have to deal with, because it may just be average and therefore prompting constant public condemnation and innumerable grievances, perhaps the environment of the social workers in the developed world has made the social workers work with higher impetus and motivation, and perhaps be able to identify and work on the miseries, and other social evils against humanity (NASW, 2014). These efforts and initiatives may be successful due to huge efforts by the social workers themselves and perhaps also due to their recognition and improved working environments (Lawler, 1994; Kang'ethe, 2011, 2014a).

Perhaps the drive and impetus of social workers themselves is a factor that can significantly contribute to increasing the state of service delivery (Kang'ethe, 2014b). In other domains, social workers have been appreciated for their efforts in preventing and dealing with trauma and post traumatic disorders in events such as the heinous and dreadful American terrorist bombing that took place on 11th September 2001 (Reardon, 2011). This indicates the selflessness, passion, dedication and commitment which social workers should embrace if they are going to largely, or significantly tackle the innumerable ills that appear to affect every corner of the globe (Reardon, 2011). Perhaps it is this same spirit that the South African social workers should also embrace considering the gravity of the social ills the country experiences. Appreciably in South Africa, the government's policy commitment to address these ills is on record more so to redress the glaring inequalities, inequities and imbalances created by the apartheid regime (White Paper For Social Welfare, 1997). On a positive note, the country needs to be hailed for its huge efforts to increase its pool of social workers year-in-year-out after the government considered the profession a scarce skills one (South African Council of Social Service Professions, 2008, 2009) with the result that the government sponsored many students to take social work in an endavour to fill in the gap

Ironically, while there are many registered social workers and fresh ones graduating year-in-year-out with an expectation of reducing the workload and therefore increase competence levels of the social workers by now, unfortunately many complaints leveled against the social workers by the public have not subsided (www.timeslive.co.za, 2013). Perhaps before blaming the competence levels of the social workers in the country, it is good to understand and appreciate the magnitude of the social ills plaguing the country. To begin with, HIVIAIDS infection rates have been very high in South Africa. Global statistics indicate that South Africa has the highest number of people living with HIVIAIDS (Ramphele, 2008).

The country in tandem with other countries in the region such as Botswana also experiences very high levels of crime and violence making some scholars to indicate the growing culture of crime and violence (Kang'ethe \& Duma, 2014) and higher statistics of various forms of gender based violence (Kang'ethe, 2014c; Gender Link, 2012; Smith 2007). Perhaps the paradox that is apparent in South Africa's social service delivery is that even though various forms of social assistance from housing to food grants are provided, poverty still persists and many more disheartening experiences are apparent (Kang'ethe \& Manomano, 2014).

Given the fact that social workers are best equipped to deal with various forms of poverty and its ramifications, stresses and strains on the people, and yet the public of South Africa continue to register the innumerable complaints pertaining to service delivery, a paper of this nature to explore the factors weighing down effective and efficient working of 
the social workers in South Africa is important. It is hoped that the paper could document pertinent challenges surrounding the role of the social workers; and also suggest the possible solutions to assist the government and other bodies to ensure that the much needed work from the social workers is not compromised.

\section{Factotrs Underpinning Poor Service Delivery by the Social Workers in South Africa}

\subsection{Poor funding or lack of finances to enhance their performance}

Globally, $40 \%$ of the world's population suffers immense poverty because their countries are resource strapped (WHO, 2002). Indubitably, a lion's share of this population lives in developing countries and suffer daunting and an uphill challenge to eke for a living. In fact more than half of the world's population live a life of less than a dollar a day. This means that their standards are below what United Nations is calling poverty bread line (UN Millennium Project, 2006; The World Bank, 2014)

Perhaps countries from Africa suffer most poverty more than other poor countries of the globe. It is ironical that despite the fact that most of these countries are now self-governing after many decades of colonial governance and administration and in South Africa apartheid, poverty and its ramifications still remains a huge norm. However, it needs to be appreciated that the standards of many of the African countries have improved albeit a little, but paradoxically, a score of them still remain trapped in a sea of poverty and it is on poverty that most of the social worker' roles and tasks is premised (Assamoah, 1994; Food and Agriculture Organization (FAO), 2012; The World Bank, 2014). In South Africa, the performance of social workers has been under scrutiny or calls for scrutiny because of the innumerable comments, complaints and grievances that have often been leveled against them and the Department of Social Development (Kirimi, , 2007). It would then be important that more research and discourse papers such as this one is used to discuss the possible environment that could be driving to social workers' unsatisfactory performance in the lenses of the public (Maughan, 2008; Dlangamandla, 2010; Wits Social Work, 2014).

While it is unarguable that there is an inextricable relation between any possible professional productivity and the remuneration or the incentives of the workers thereof (Kang'ethe, 2011), it is important that a profession will ideally need remuneration that will motivate optimum performance to ensure that the government's vision of serving the citizens with optimal satisfaction is reached. Unfortunately, the innumerable complaints in various corners of the country heralds a system that has no motivation, perhaps due to meagre or inadequate remuneration among other working factors such as poor infrastructure or even competence levels to handle its requisite tasks (Kirimi, 2007). This is ironical since the Department of Social Development is on record for subsidizing salaries for the social workers working in the NGO fraternity. However, whether the end result remuneration is something to drive satisfaction or incentive is another angle to be considered because all in all, low pay across a barrage of the social workers has been a constant outcry (Department of Labour, 2008). Perhaps the salary awarded should consider the workload of the social workers. Perhaps due to huge service especially to effectuate registration and administration of social grants across different categories of population groups, the South African social workers' working load has been a heavy one, sometimes one individual social worker having to handle 300 cases a day. This may constitute a heavy caseload and an overwhelming environment (Schenk 2006; Kang'ethe, 2014a). This state of affairs accounts to the high levels of demotivation and therefore diminished capacities and output.

\subsection{Lack of infrastructure and resources to support their work}

Indubitably, and in any work environment, an inextricable relationship exists between work productivity and the state of infrastructure and tools available. A good environment with effective and appropriate resources and infrastructure has a motivational effect to the workers (Kang'ethe, 2011). Taking the case of South Africa, most social workers in South Africa are involved in work that needs them to be close to the target beneficiaries of the programme they are representing. In most cases, the organizations they work for, whether government or NGOs do not provide adequate infrastructure and appropriate tools to ensure optimum benefit and motivation (Lawler, 1994). Lack of, for example, appropriate office and associated infrastructure such as office equipment and vehicles impedes the work of social workers until they cannot make significant impact on the communities they are serving. Other anecdotal evidence indicates that social workers are expected to do too much amid limited resources and this has contributed to making the social work profession a crisis on its own (Department of Labour, 2008). Thus, resources play a very important role as they assist the employee to enjoy, gain confidence and feel human in the work place at the same time. This is because an inadequately resourced work place can result in stress and depression because of the hardships within which the employee is supposed to operate 
from (Schenck, 2006; Kang'ethe, 2011).

\subsection{Poor supervision affecting their growth and professionalism}

Unarguably, effective and competent supervision is key to drive optimum productivity and also to keep the workers on track to reaching their task goals (Social Care Institute for Excellence (SCIE), 2012). Indubitably, supervision is an important element in the professional growth and development of social workers (Davies 2000 as cited by Sokhela, 2007; SACSSP, 2008, 2009). Effective supervisors are able to guide, direct, advice, correct and even cardinalate the report writing skills and the tempo of the social workers. This protects and safeguards both the professional growth of the workers and also the organizations they serve. Effective supervision also adds working motivation to the workers (Lawler, 1994; Trevithick, 2004; Kang'ethe, 2011). It is unfortunate that in some occupational settings in South Africa, some social workers indicate poor or no supervision for a longer period of time, with no learning or developmental needs identified. Such environments, no doubt are de motivational, offers no opportunity for growth and does not ensure that one is professionally on track. Such scenario indicates a recipe of incompetence and diminished productivity (Sokhela 2007; SACSSP, 2008, 2009). This state of affairs paints a very bad picture regarding the social work profession as the professional bars have been lowered to a very low ebb. Unavailability or lack of supervision or even poor quality supervision can have detrimental effects on the development and service delivery that social workers offer to the general public. Given that South Africa has many developmental initiatives in that it is one of the countries in the globe with the hugest social welfare, more needs to be done to address these gaps and flaws.

\subsection{Poor implementation of policies to secure social workers in their service delivery}

Indubitably, strong policy environment bolstering the security of any occupational setting is critical in strengthening the service delivery and motivation of the workers thereof (Kang'ethe, 2010). Some researchers have shown that an inextricable relationship exists between occupational security and work motivation. For example a research by Kang'ethe (2010) in Botswana showed that informal caregivers suffered a state of demoralization and demotivation because of the realization that while nurses were covered by the workers' compensation Act No 23 of 2001 of the laws of Botswana that provides for the compensation of workers for injuries sustained or occupational hazards arising in the course of employment or death from such injuries or occupational diseases, them they were not, although they were on duty for almost 24 hours with the sick clients they were taking care of (Kang'ethe, 2006).

Equally in South Africa, the policies pertaining to covering the social workers occupationally are apparently not adequately operationalized. For instance, reports have indicated that some social workers have lost their lives whilst on duty and yet no occupational compensation has been effected (National Association of Social Workers (NASW), 2008). This indicates a serious policy gap that need serious scrutiny and redress. Perhaps the issue of covering the workers against occupational hazards make the workers of developing countries different from those of developed part of the world. In developed world, workers are adequately covered and will be fully compensated for any loss and damage one face while on duty (European Commission, 2010). This can to some extent explain the level of morale and motivation between the workers of the developed world and those of developing countries. Perhaps the scenario may also partly explain why many social workers from African countries have been migrating to developed world (Kang'ethe, 2014a).

\subsection{Challenges associated with competence levels among the social workers}

Although social work is a noble profession, apparently the social workers especially in developing part of the world are expected to handle all aspects of the problems besetting any society. They are usually trained to be generalist to handle an array of tasks and roles. They are supposed to be professionally (Segal et al, 2007; Sheafor \& Horejsi, 2008). However, sometimes they may be challenged to handle some aspects of a social the problem. For example at the advent of HIVIAIDS in Botswana and South Africa, many social workers were not competent to handle many aspects of it. They had to take time to understand the professional terrain. This is because the Bachelor of social work curriculum may not have been thorough in training the social workers in some deep aspects such as those of psychoanalysis which are adequately clarified at Masters Levels (Kang'ethe, $2014 \mathrm{~d}$ ). However, there is assumption by the public that social workers are adequately equipped to handle all the ills besting the society. Perhaps this could explain community dissatisfaction by the social workers in countries such as South Africa and Botswana (Kang'ethe, 2006). Courses such as advanced clinical social work are usually adequately handled (Kang'ethe, $2014 \mathrm{~d}$ ). 


\section{Recommendations}

In light of the findings that have been documented in this study, the following recommendations have been put forward:

- There is need for programmatic and policy review to ensure that social workers in South Africa are protected and enabled to provide services to the people and in any context in South Africa.

- The emphasis of inter-governmental collaboration needs to be reinforced and strengthened so that government departments and both public and private bodies can work together in harmony towards easing the social problems that people face and this will also assist social workers in their work and profession.

- Establishing appropriate funding mechanisms will also go a long way in ensuring that the social workers are properly remunerated and their salary scale above norms as they are serving people in difficult and overwhelming ways. Importantly, social workers should not be over emphasized but should be recognized properly and financially. This will also benefit and reduce the many social ills that confront South Africa.

- Ensuring that social workers where applicable have access to supervision is mandatory and needs to be effectuated in the country and the promotion and training of those supervisors is critical to ensure that they render correct and appropriate supervision to the supervisees. The availability of resources and infrastructure may need the country to increase its budget towards social development to ensure that social workers are properly and adequately resourced.

\section{Conclusion}

These researchers commends the government of South Africa for ensuring that the profession of social work has its own niche through allocating the Department of Social Development as a responsible organ and creating an enabling environment for social workers to be housed in NGOs fraternity. However, the many challenges that the social workers face indicate that there is a lot of steps and actions that need to be taken to ensure that social workers are protected and are working in a conducive environment. It is hoped that this paper will provoke and stimulate both the government and non-government to consider improving the situations of social workers in the country.

\section{References}

Assamoah, Y. (1994). Challenges to Social Work around the World: Africa" (1994). Center for International Social Work: Inaugural Conference (1994).Paper 6. Available at http://digitalcommons.uconn.edu/sw_intlconf/6. Accessed on 14/4/2014.

Department of Labour (2008). Social Work As A Scarce And Critical Profession. Scarce and critical skills research project. Available at www.labour.gov.za. Accessed on 14/04/2014

Dlangamandla, P.V (2010). The experiences of social workers regarding the implementation of a developmental social welfare approach within the Department of Social Development Gauteng Province. Masters Dissertation. University of Pretoria Electronic Theses and Dissertations. South Africa.

European Commission (2010). Occupational Health and Safety risks in the health care sector. Guide to prevention and good practice. European Commission. Available at www.insht.es. Accessed on 30/08/2014

Food and Agriculture Organization (FAO) (2012). "The state of food insecurity in the World 2012". Available at http://www.fao.org. Accessed on 30/08/2014.

Gender Link (2012). The Gender based Violence indicators study Botswana.http://www.genderlinks.org.za/article/the-gender-basedviolence-indicstudy-botswana-2012-03-28

International Federation of Social Workers (IFSW) (2012). Poverty Eradication and the role of social workers. Available at www.ifsw.org. Accessed on 30/08/2014

Kang'ethe, S.M (2006). Contribution of caregivers in community home based care programmes. The case of Kanye, Botswana. Unpublished dissertation in Social Work, Department of Social Work, North West University, Mafikeng

Kang'ethe, S.M. (2010). Occupational care giving conditions and human rights. A study of elderly caregivers in Botswana. IJPCJuly-Aug 2010l. 16(2.) 86-89.

Kang'ethe, S.M (2011). Exploring the awarding of incentives to caregiving productivity in Botswana. Maatskaplike Werk 2011: 47(1) P/114

Kang'ethe, S.M \& Duma, V. (2014). Exploring Dimensions of Post -Apartheid Xenophobic Sentiments Towards African Immigrants in South Africa. Insight on African, India 5, 2 (2013): 157-168

Kang'ethe, S.M \& Tatenda Manomano (2014). Evaluating the Ownership Spirit Displayed by the Golf Course RDP Housing Programme Beneficiaries with evidence emanating from the 2011-2013 Research Study. Journal of Human Ecology. 46(1): 11-19

Kang'ethe, S.M (2014a). Exploring social work gaps with examples from South Africa and Botswana: In the press of Journal of Social Sciences.

Kang'ethe S.M (2014b). The impetus of Social Work as a catalyst to the achievement of Millennium Development Goal number three in 
selected African countries. A literature review. Mediterranean Journal of Social Sciences Vol .5, Number 8. Page 604-609.

Kang'ethe, S.M (2014C). "The Woman and the Girl Child Phenomenon and Gender -based Violence (GBV) in Botswana" in the book" Human Rights and Social Equality: Challenges for Social Work. Ashgate Publishers. (1) 125-132.

Kang'ethe (2014d). Exploring the possible gaps associated with the current practice and application of psychodynamics in contemporary clinical settings in some African countries. Mediterranean Journal of Social Sciences. 5 (8) 539-543.

Kirimi, K. (2007). Social Development Portfolio Committee South African Council for Social Services Profession: Briefing \& Role of Social Workers in Substance Abuse Treatments: Briefing. Available at www.pmg.org. Accessed on 14/04/2014

Lawler, L.L. (1994). Motivation in work organizations: San Francisco: Jossey-Bass.

Manomano, T (2013). The perceptions of the Reconstruction and Development Programme (RDP) Housing beneficiaries in South Africa on the extent to which the project meet their Housing needs: The case of Golf Course Estate in Alice Town, Eastern Cape Province. Master of Social Science Social Work Dissertation. South Africa: University of Fort Hare.

Maughan K. (2008). Mother tackles social worker. IOLNEWS. Available at www.iol.co.za. Accessed on 30/08/2014

National Association of Social Workers (NASW) (2008). NASW WV Statement: Social Worker NASW (2014). Social Work History. Available at www.socialworkers.org

Ramphele, M (2008). Laying Ghosts to rest. Dilemmas of the Transformations in South Africa. Cape Town: Tafelburg.

Reardon, C. (2011). A Decade of Social Work Today-10 Trends that transformed Social Work. Social Work Today. 11 (4) 10.

Schenk, M. C. (2006). Social Worker in South Africa explains it all. Child and Youth rights globalization. Panorama. Available at www.tigweb.org. Accessed on 14/4/2014

Segal, EA, Gerdes,K. E \& Steiner, S. ( 2007). An introduction to the profession of Social Work. Becoming a change agent. Second edition. Thomson. Brooks/Cole.

Sheafor, B. W \& Horejsi, C. R (2008). Techniques and guidelines for Social Work Practice. Allyn \& Bacon. Boston, London, Sydney \& Toronto.

Sokhela, M. P. (2007). Intergovernmental relations in the local sphere of government in South Africa with specific reference to the City of Tshwane Metropolitan Municipality.

Smith B (2007). Finding solutions to complex social problems in South Africa. This article was prepared for the 2006 annual report of the Social Change Assistance Trust. Synergos Learning Library.Social Care Institute for Excellence (SCIE) (2012). Effective supervision in social work and social care. 43 released briefing. Available at www.scie.org.uk. Accessed on 30/08/2014 South African Council for Social Service Professions (SACSSP). (2009). Policy on Continuing professional development (CPD) of persons registered with the South African Council for Social Service Professions (SACSSP).

South African Council for Social Service Professions (SACSSP). (2008). Letter. Continuing Professional development (CPD) provincial meetings. Ref: 12/9.10 March.

The World Bank (2014). Poverty Overview. The World Bank. Available at www.worldbank.org. Accessed on 30/08/2014

Trevithick P 2005. Social Work Skills. A Practice Handbook. Two Penn Plaza, New York, NY, USA.

United Nations Department of Economic and Social Affairs (UN-DESA) (2013). Online Survey on Promoting Empowerment of People in achieving poverty eradication, social integration and full employment and decent work for all. Available at www.un.org/ desadesa.org. Accessed on 30/08/2014

UN Millennium Project (2006). UN Millennium Project. Available at www.unmilleniumproject.org. Accessed on 30/08/2014

Wits Social Work (2014). Social Work as a Profession. University of Witwatersrand. Available at www.wits.ac.za. Accessed on 30/08/2014.

White Paper For Social Welfare. (1997). A policy document issued under the auspices of the Ministry for Welfare and Population Development. Pretoria, February, 1997.

WHO. (2002). Community Home -Based Care in Resource- Limited Settings. A Framework for Action. 20 Avenue Appia, 1221 Geneva 27, Switzerland.

www.timeslive.co.za 2013. KZN Social worker suspended after rape charge. (Online News 22 November 2013). Accessed on $31 / 08 / 2013$ 